\title{
China-ASEAN Free Trade Area of E-commerce Development
}

\author{
Wang Molin \\ International Business School \\ Yunnan University of Finance and Economics \\ Kunming, China \\ Hongkun Li* \\ Accounting School \\ Yunnan University of Finance and Economics \\ Kunming, China \\ 310173882@qq.Com
}

Yongsong Liu

\author{
International Business School \\ Yunnan University of Finance and Economics \\ Kunming, China \\ Lisheng Yang \\ International Business School \\ Yunnan University of Finance and Economics \\ Kunming, China \\ Duan Yunlong \\ International Business School \\ Yunnan University of Finance and Economics \\ Kunming, China
}

\begin{abstract}
Create a board upgrade of China-Asean Free Trade Area, e-commerce plays a very important role, its current development still exist many problems, actively explore how to improve the service system, to build the "One Belt, One Road", electricity supplier ASEAN new strategic platform, for the free trade area development is very important.
\end{abstract}

Keyword-China-Asean Free Trade Area; e-commerce; development.

\section{INTRODUCTION}

Li Xiangyang (2014) pointed out that in order to promote the development of cross-border e-commerce, enhance the competitiveness, we must attach importance to the construction of cross-border logistics network [1]. Zhao Xuming and Yang Xiaohan (2016) believe that cross-border ecommerce has led to the growth of foreign trade, improve the management of China's foreign trade enterprises [2]. Wang Lin and Yang Jianzheng(2014) concluded that marketing capability and logistics is the key to the development of crossborder e-commerce [3]. Huang Qing (2013) pointed out that the advantages of cross-border e-commerce in China:Based on traditional trade and better than traditional trade, and there is the support of the government. In the era of rapid development of network economy, electronic commerce is both an opportunity and a challenge for the development of national economy. The government should take appropriate measures to encourage and support the development of e-commerce [4].

In recent years, e-commerce as a new way to trade is developing rapidly, the ever-changing Internet technology and maturing transactions of public platform to make it more and more to play a important role. Today, e-commerce is becoming an important force in the further expansion of global trade and stimulating new economic growth, so e-commerce in

\footnotetext{
* Corresponding author
}

China-Asean Free Trade Area will have a broad foundation for the development and prospects.

\section{ChINA-ASEAN FreE TRADE AREA E-COMMERCE DEVELOPMENT ENVIRONMENT}

Facing a new round of global e-commerce business model innovation, cross-border cooperation and global e-commerce expansion trend is obvious. At present, China-Asean Free Trade Area of the electronic commerce environment opportunities and difficulties coexist, mainly reflected in:

\section{A. Economic development level differences lead to the popularity of e-commerce is not high.}

There are huge differences in the level and stage of economic development between ASEAN countries, newly industrialized countries, Singapore's per capital GDP is nearly \$3 million, Vietnam, Myanmar, Laos, Cambodia and other four of the world's most developed countries, per capital GDP is less than $\$ 400$, both per capital GDP difference of about 70 times, suggesting that many ASEAN countries is still in a low stage of economic development. In the low economic development environment, the development of e-commerce is still at a low level. Therefore, China-Asean Free Trade Area of e-commerce is still in the cultivation stage of the market, it takes time to slowly change the concept of consumption, and gradually enhance the purchasing power of electronic commerce [5].

\section{B. Cross-border e-commerce support system is facing new challenges}

With the deepening of the construction of the China-Asean Free Trade Area, related to the infrastructure, customs, inspection and quarantine, finance, port, logistics, information and communication field of ancillary services bring forward 
new requirements, But the cooperative service, infrastructure construction and others are still at a low level, mainly reflected in the following aspects: First, customs clearance and tax cooperation mechanisms need to be improved. Asean countries in different markets, customs, logistics, customs clearance and other operations and regulatory are very different, the establishment of mutual penetration of the highly efficient cooperation mechanism has a considerable difficulty [6]. Second is an urgent need to improve the comprehensive financial services supporting mechanism. China-Asean free trade area is facing an important issue is to establish a modern financial open cooperation platform to promote the integration of China and the Asean countries to pay the liquidation. Third is the interconnection of infrastructure is still relatively backward. At present, trade between China and Asean mainly through the road and rail transport to complete the transfer, road network, professional market, regulatory inspection and other infrastructure is backward, be badly in need of strengthening construction. And because of the high cost of transportation, transporting quantity is not big, transport of goods between China and ASEAN countries at present very few choose air freight.

\section{The sustainable development of China's economy provided strong impetus for China - Asean free trade area construction.}

In recent years, due to the economic going downturn in the United States, Japan and other countries, so they have implemed of free trade protection measures, but it bring a serious blow to the Asean countries' economic, the economic growth rate slowed significantly. With the further development of the Internet era, e-commerce is becoming a further expansion of global trade and an important force that stimulate new economic growth, China currently has more than 5, 000 e-commerce platform, more than 200, 000 companies. The strong momentum of China's economic development will benefit the people of Asean countries and the construction of China-Asean Free Trade Area, by 2015 China-Asean bilateral trade volume will reach $\$ 500$ billion, the bilateral trade volume in 2020 will reach $\$ 1$ trillion. Xi Jin ping proposed the construction of the Silk Road Economic Belt and the twenty-first Century Maritime Silk Road, the great strategy, more conducive to accelerate the development of e-commerce in the free trade zone.

\section{The Problem OF ELECTRONIC COMMERCE IN CHINA- ASEAN FREE TRADE AREA}

China-Asean Free Trade Area development is facing the unprecedented opportunity for development, but due to the influence of many factors such as countries national policy, economic, legal and cultural environment, the development of cross-border e-commerce also faces many problems and difficulties [7].

\section{A. E-commerce laws and regulations are not perfect.}

For China-Asean Free Trade Area, the lack of e-commerce laws and regulations with integrated or regional jurisdiction, resulting in increased e-commerce disputes, to a certain extent, affected the development of e-commerce. Therefore, how to further establish and improve laws and regulations with a regional e-commerce, the establishment of an electronic trade information, the authenticity and the identity of both parties to ensure the accuracy of the mechanism, is China-Asean Free Trade Area of the important development of e-commerce need to be addressed.

\section{B. International logistics system construction lag.}

E-commerce has the advantage of high efficiency and convenient, so logistics is the key factor that electronic commerce can carry out smoothly, FTA development of ecommerce can not be separated from a low cost, high efficiency, timely, appropriate logistics system, otherwise, the advantages of electronic commerce will be difficult to effectively play [8]. In recent years, Asean logistics infrastructure network has the very big development, but among the member states of FTA in the interconnection infrastructure is still relatively backward, most countries logistics information level is low, the utilization of information resources has not yet been achieved cross sectoral, cross industry integration, information sharing level is low. Logistics service standards are uneven, logistics unified terminology, operations, data transmission and other standards yet to be unified.

\section{E-commerce security issues outstanding.}

With the growing popularity of network technology, hacking increasingly rampant, security issues become increasingly prominent in the development of e-commerce, mainly network protocol security, user information security, ecommerce site security and other issues. Therefore, how to use more advanced security techniques to build a complete, secure e-commerce, a reliable security system, it can not be ignored.

\section{Network electronic trading payment is not smooth}

Currently, there are many kinds of currency and ecommerce payment methods in Asean countries, and each method has its own characteristics, when electronic trading parties using different payment methods, the two sides can not be paid through the means of electronic payment and thus the online transactions cannot be achieved [9]. The development of electronic commerce is not only to have a support of network, but also need some public network trading platforms. However, the non unification of payment methods and currency exchange in cross-border transactions have become a prominent problem in the electronic payment of Asean countries. Therefore, the establishment of an integrated electronic payments network, unified the various payment methods, is the problem that current urgent need to solve in China - Asean Free Trade Area.

\section{The Strategy About China-Asean Free Trade AREA ElECTRONIC COMMERCE DEVELOPMENT}

\section{A. Improve the system and services.}

China-Asean Free Trade Area of e-commerce market has great potential, but also face trade rules, customs and tax policy, development patterns, government regulation and many other issues, the recent focus on China should address the following three aspects: First, efforts to achieve government collaboration. China - Asean Free Trade Area to build a network of e-commerce trade, the establishment of 
mechanisms for coordination and management is the key area of trade, should have special agencies responsible for the business negotiation, organization and coordination of network trade and related management work, developing and improving access conditions for trade networks. Second, the establishment of cross-border economic cooperation zones. In cross-border economic cooperation zone, taking half bulk assembly or direct assembly, finished product assembly assembly production products, obtain the certificate of origin, can bypass the ASEAN countries on China's import tariff barriers, improving the competitiveness of China's products in the Asean market. Third, the gradual deepening of customs clearance facilitation reforms. Further promote the integration of the border departments of information systems, improving customs clearance efficiency.

\section{B. Reduce cross-border logistics costs, upgrade cross-border electricity suppliers.}

Accelerate FTA logistics cooperation should focus on the following three aspects: First, accelerating the construction of infrastructure interoperability. At the same time, it is necessary to speed up the construction of border trade center, to promote the liberalization and facilitation of trade in goods. Second is to establish overseas warehousing [10]. The establishment of storage in the country of destination, the half of the goods exported to the storage and distribution to consumers, not only low cost, but also due to solving the employment of local labor and tax issues will be welcomed by the exporter. Third is to accelerate the construction of electricity suppliers industrial base. To further accelerate the plan and construction of China-Asean e-commerce platform base, to promote the integration of online markets and offline markets, to further gather, strengthen cooperation with the Asean electricity supplier industry.

\section{Speed up the cultivation of talents.}

In recent years, the cooperation between China and ASEAN in the construction and application of e-commerce network has made some achievements, but we can also see that the results are not very obvious, the space is still very large, we must jointly consult the revised "information superhighway" or network infrastructure technical standards. At present, China and ASEAN countries should according to the different network technology standards and make plans to organization international dialogue and consultation, invite the relevant international organizations, network-expert, factories and enterprises to jointly study and joint development of unified international technical standards or regional network technology standard. Talent is the basis of development and innovation, to ensure the rapid development of e-commerce, we must increase the training of talents in electronic commerce. Asean universities in personnel training should focus on the following three aspects: First, the application of the university to carry out the construction of the corresponding disciplines of electronic commerce. Second, the joint development of colleges and universities to cultivate talents. Third, to strengthen research on issues related to electronic commerce technology, marketing, management, security and other related issues.

\section{Establishment of third-party payment system to achieve a cross-border electronic payment in free trade area.}

Currently, the exchange rate between the ASEAN countries is constantly changing, it has a direct impact on people's desire to develop the potential of the e-commerce purchase. The best solution is to automatically exchange the currency of the software is integrated in the electronic business server, to achieve regional e-commerce services [11]. Countries in the free trade zone should pay more attention to the problem of online payment, and construct the third party payment system is an effective solution for the realization of cross-border electronic payment in China - Asean Free Trade Area. At present, Alibaba China, Singapore trade nets and other multiple influential transnational e-commerce trading platform active in the free trade zone, they are playing an important role in ChinaAsean SME e-commerce. Asean countries should establish ecommerce certification center as soon as possible, establishment of an authoritative and independent non government certification body in the regional scale.

\section{SUMMARY}

The China-Asean Free Trade Area (CAFTA) has been entirely put in place by 2010. As an emerging mode of trade, e-commerce plays an active role on trade between China and ASEAN. By analyzing the environment of E-commerce in CAFTA, exploring the advantageous factors to expedite Ecommerce, working out the countermeasure of e-commerce within CAFTA, which has important significance for prompting e-commerce.

Anyway, all the countries in the China-Asean free trade area must grasp the opportunity, making full use of their respective advantages, promoting trade and investment, cultivating business platform, to construct a suitable for their own development electronic commerce application mode, together to create the environment of innovation and the development of e-commerce, to jointly promote the growth of the economy of ASEAN.

\section{ACKNOWLEDGMENT}

This work was supported by National Natural Science Foundation Project(71262016); National Natural Science Foundation Project (71663058), and National Natural Science Foundation Project (71663062). At the time of completion of this paper, First of all, thanks to my tutor, Duan Yunlong, for his help in the design, implementation, and writing process of my paper. This topic is under the tutor's careful and earnest care to complete, heartfelt thanks to the teacher Duan for my education, as well as my life, work, study, research and other aspects of selfless help. At the same time, thanks also to the help of other teachers, so my paper there can be well done. Secondly, I would like to thank my classmates those who have supported me in silence, please accept my sincere thanks. In the end, I would like to express my sincere gratitude to all the people who care about me, love me and give me help. 


\section{REFERENCES}

[1] X.Y. Li, "The path to promote the development of cross-border ecommerce logistics," China Business and Market, pp. 10-11, October 2014.

[2] X.Y. Zhao and X.H. Yang, "Analysis on the impact of the development of cross-border e-commerce on China's foreign trade model," Journal of Commercial Economics, pp. 15-16, April 2016.

[3] L. Wang and J.Z. Yang, "Analysis on the factors affecting the performance of international logistics -- Based on two market theory and structural equation model," China Business and Market, pp. 7-8, May 2014.

[4] Q. Huang, "Research on the role of electronic commerce in the development of local government," China Journal of Commerce, 2011.

[5] H.Y. Liang and H.Y. Liu. "China-Asean free trade area analysis and countermeasures," Journal of electronic commerce environment aspect of southeast Asia, 2000, pp. 12-12.
[6] J. Hu, "China-Asean Free Trade Area electronic commerce cooperation idea," reform and strategy, 2004, pp. 10-10.

[7] X.H. Xue, "Six major issues to be solved in China's e-commerce legislation," Communications World, 2006, pp. 28

[8] Z.J, Zhang, "Study on the legal issues of service trade in China-Asean Free Trade Area," Guangxi Normal University, 2007

[9] L. Xing, "Problems and solutions in the development of China's ecommerce," Market Modernization, 2007, pp. 7-8.

[10] D.W. Liu, "The impact of Electronic Commerce on the development of international trade and China's coping strategies," Economic research Herald, 2012, pp. 28-29.

[11] W.J. Fan, "The development of cross-border e-commerce and the transformation of China's foreign trade model," International trade and economic cooperation, 2015, pp. 4- 7. 